\title{
Interest Rate and Inflation Nexus: ARDL Bound Test Approach
}

\author{
MUSA $^{1 *}$, Kabiru Saidu $\quad$ RABIU ${ }^{2}$, Maijama'a $\quad$ NASIRU $^{3}$, Mahabub $\quad$ SAMBO $^{4}$, Hamza Aminu \\ 1.Department of Economics, Faculty of Social and Management Sciences, Bauchi State University Gadau P.M.B \\ 062, Yuli Campus, Bauchi State - Nigeria \\ 2.NNPC Sales Representative Bauchi Branches, Nigeria National Petroleum Cooperation \\ 3.Department of General Studies, College of Basic and Preliminary Studies, Umaru Ali Shinkafi Polytechnic \\ Sokoto P.M.B 2356, Sokoto State of Nigeria \\ 4.Enforcement Department, Social Insurance Trust Fund Office Bauchi Branch, Bauchi State of Nigeria
}

\begin{abstract}
The paperestimates the impact of interest rate on inflation in Nigeria. The study makes used of Autoregressive Distributed Lag model (ARDL) on time series Data, for the period 1970-2016. The data set on inflation, money supply, interest rate, GDP per capita and exchange rate were tested for stationary using ADF, PP and KPS tests and established stationarity at I (1) for all the variables. ARDL testresults reveal that interest rate is inflationary in both the short-run and long-run as it positively and significantly influencing inflation in the two periods which is in conformity with the arguments of the fiscal policy supporters but contradict the arguments of the monetary policy supporters. The findings of the study imply that interest rate in Nigeria is inflationary. Meaning that increase in the rate of interest rate will lead to an increase inflation rate. Therefore, the research study conclude that interest rates should be adjusted with caution, and also implies that fiscal policy measure will be very effective in converting inflation in the country.
\end{abstract}

Keywords:ARDL Bound Test, Interest Rate, Inflation, Exchange Rate, Fiscal Policy, Monetary Policy.

DOI: $10.7176 / \mathrm{JESD} / 10-20-07$

Publication date:October $31^{\text {st }} 2019$

\subsection{INTRODUCTION}

The nature of the effect of interest rate on inflation globally is not yet settled. The theoretical account of this argument (effect of interest rate on inflation) is conflicting. The supporters of monetary policy - the monetarist perceived interest rate to have inverse effects on inflation. Whereas, those who support fiscal policy - the fiscalist - argued that the nature of the effect of interest rate on inflation is direct and positive. The reports from empirical findings by researchers are more conflicting, because, in addition to positive and negative effects of the interest rate on inflation reported, some researchers also reported the insignificant effect of interest rate on inflation (Danlami et al., 2018).

The objectives of interest rate in Nigeria include but not limited to the moderation of in inflation, financial savings and investment, encouragement of reduction of pressure in the balance of payments achieving favorable exchange rate stability and promotion of macroeconomic and financial sector. Interest rate in Nigeria has been affected by the incidence of oligopolistic structure of Nigeria banking system (Ajayi et al., 2017).Interest rate management has passed through two main approaches in Nigeria namely direct and indirect approaches. The direct approach entails the administrative adjustment of lending rate and saving rates, while the indirect approach relies on the mutual effect of market forces, all the above approach tends to have its own way of inducing economic growth. The Central Bank of Nigeria retains the discretionary power to intervene in the money market to ensure orderly development of interest (Ajayi et al., 2017).

The Nigeria government has since 1987 been pursuing a market determined interest rate which does not permit a direct state intervention in the general direction of the economy (Nyong, 2001). In January, 1994 there was another policy reversal, this time the government had rightly introduced some measures of regulating interest rate management. It was claimed that there were wide variation and unnecessarily high rate under the complete deregulation of interest rate. Immediately, deposit rates were once again set up at 12 percent per annum from the previous 8 percent while a ceiling of 21 percent per annum was fixed for lending. The gap of interest rates introduced in 1994 was retained in 1995 with little modification for flexibility (Ajayi et al., 2017).

On the hand inflation is generally used to described a situation of rapid, persisted and unacceptably high rises in the general price level in an economy, resulting to loss of purchasing power of the currency. Inflation causes serious discomfort for consumers, investors, producers and the government (Asogu, 1990). Long term inflation occurs when the money supply grows at a faster rate than the output of goods and services. This situation occurs when there is more money than is needed is to accommodate nominal growth in output, consumers and business want to purchase more goods and services than can beproduced with current resources (labour, materials, etc.) causing upward pressures on prices. Over short term, inflation can occur from various shocks in the economy. Food and energy shocks are common examples of this type of inflation in Nigeria. A price of commodity such as fuel may rise suddenly and sharply, relatively to other commodities prices response, may result to short term 
increase in overall prices (Raymond, 2014).

Inflation in Nigeria has been accelerating since 1960s and has become a major concern to the government. Several policies were introduced to control inflation in the economy and despite these policies, inflationary trends continue to fluctuate. Government needs to control high level of unpredictable inflation since it can severally disrupt the economy. The tools governments normally use includes monetary policy (i.e. increase or decrease in the money supply and interest rate), fiscal policy (changes in the amount of taxes and government spending) and various controls prices, tariffs, etc. Many nations choose monetary policy as their primary tool since it has proven to be effective, less disruptive to the market operations and easier and quicker to implement since adjusting the money supply does not require legislative approval as would be for instance changing the tax structure (Raymond, 2014).For several decades now, interest rates had always been a problem in the Nigerian economy ever since the late 1980s when interest rates were deregulated. There has always been complain about high interest rate in the country. So far, the government has not been able to address the issue. (Iweala, 2013).

Thus this paper is motivated by a number of reasons notably: the need to reduce the rate of inflation; absence of consensus on the exact relationship between interest rate and inflation and gap in the contemporary related literature in Nigeria on the impact of interest rate on inflation.

Therefore, this paper examines the impact of interest rate on inflation in Nigeria. The contribution of the paper to scientific knowledge is as follow. Unlike other Nigerian literature, the paper investigates the impact relationship between interest rate and inflation considering money supply, per capita GDP and exchange rate. In addition, the paper contributes to the inconclusive debate on the literature regarding the exact relationship between interest rate and inflation in Nigeria. Furthermore, to best of our knowledge, the use of ARDL in Keynesian inflation model for Nigeria has not been included in the literature. Finally, the findings of this paper will serve as a guide for policy making on interest rate and its impact on inflation in the country. It will equally provide empirical backing for some existing policies and programmes targeting interest rate to reduce inflation in Nigeria.

The paper is organized as follows. Section 1 present the general introduction. Section 2 focusedon the literature review and theoretical framework. Section 3 described the model and data. This includes the econometric technique and sources of data. Section 4 reported the estimation results and discussion while Section 5 handle the conclusion.

\subsection{LITERATURE REVIEW}

\subsection{Empirical literature review}

There are numbers of empirical literatures on the effect on interest rates on inflation rates, but their findings are inconclusive. Some studies reported positive or direct influence such as Bayo (2011), Adu and Marbuah (2011), Raymond (2014) and Mbutor (2014). While some studies reported negative or inverse influence and such studies includes Babalola et al.(2015) and Umoru and Oseme (2013). A lot of studies reported inconsistent result of interest rates influence inflation rates dynamics such as Amaefula (2016), Ifionu and Ibe (2015), Udo and Isaiah (2018), Ndidi (2013), Alexender et al. (2015) and Odusanya and Atander (2015).

\section{Positive relationship}

Bayo (2011) investigate the determinants of inflation in Nigeria between 1981 to 2003 . Using OLS to analyze secondary data on fiscal deficits, money supply, interest rate and exchange rates, the result shows that all the variables significantly and positively impacted on the rate of inflation in Nigeria. While the explanatory variables accounted for $72 \%$ of the variation in inflation in Nigeria during the period of study with the error term capturing $28 \%$ of the variation. He concluded that the causes of inflation in Nigeria are multi-dimensional and dynamic, requiring full knowledge at any point in time to be able to prefer solutions to the inflationary trends in the country to lead to high productivity and increased living standard of the citizenry.

Adu and Marbuah (2011) provide an empirical analysis of the factors accounting for inflation dynamics in Ghana using the bound test and other econometrics approaches. The findings revealed that real output, nominal exchange rate, broad money supply, nominal interest rate and fiscal deficit play a dominant role in the inflationary process in Ghana. The extent that output growth by far has the strongest impact on inflation, targeting supply-side constraints will help moderate price inflation. They conclude that inflation in Ghana is explained by a combination of structural and monetary factors consistent with prior studies.

Mbutor (2014) study the relationship between inflation and money supply in Nigeria using VECM. The data set spanned 1970 to 2012 on GDP, nominal exchange rate, maximum lending rate, inflation (i.e. CPI), broad money supply. All the variables were stationary at I (1) except GDP and CPI who were stationary at I (0). The cointegration test results detected co-integration among the variables. The impulse response function showed a persistent positive relationship between inflation and money supply while variance decomposition of inflation shows that GDP was the strongest contributor to inflationary pressure in Nigeria, and that money supply accounts for up to 3.5 percent of aggregate price changes

Raymond (2014) examines the effect of changes in interest rate on inflation measured by CPI in Nigeria using both the descriptive and econometric methods. Set of data on money supply, interest rate, CPI, minimum 
rediscount rate, prime lending rate and treasury bills rate for the period of 1980 to 2010 were considered. The empirical results confirm that changes in interest rates and increase in the level of money supply were associated with rise in inflationary pressure. The study concludes that the relevant authority to correct abnormality in inflation rate through the introduction of appropriate interest rates from time to time.

\section{Negative relationship}

Umoru and Oseme (2013) estimates the relationship between inflationary expectations and the variations in interest rate in Nigeria using the Generalized Method of Moment (GMM) estimator. Using ADF and PP tests all the variables were stationary at first difference. The Johansen co-integration test results revealed all the variables move together in the long run. The GMM result shows that interest rate impacted negatively and significantly on inflation. They conclude that variation in prime lending is a determining factor of inflation expectations in Nigeria. Therefore, CBN should persistently vary the prime lending rate in order to check inflation expectations in the country.

Using secondary data on inflation rate, interest rate, net deposit credit and transfer payments for the period of 1981-2014. Babalola et al. (2015) determine the effect of inflation rate and interest rate on economic growth. The study adopted Ordinary least squares (OLS) method of analysis. Augmented Dickey Fuller test show that all the variables were integrated at I (0) except inflation rate. Long run relationship between the variables was established using Johansen integration test. The direction of causality and trend analysis was also performed on the variables. The result shows that inflation and interest rate has negative effect on economic growth but neither the inflation nor the interest rate granger causes economic growth. They recommended that policy makers should focus on maintaining inflation at a low rate (single digit) and ensuring interest rate stability.

\section{Inconsistent results}

Odusanya and Atander (2015) Analyzed the dynamic and simultaneous inter-relationship between inflation and its determinants in Nigeria between 1970-2007. The time series variables properties were examined using the Augmented Dickey-Fuller (ADF) unit root test and result reveals that inflation rate, growth rate of real output and money supply, and real share of fiscal deficit are stationary at levels, while other real share of import, exchange rate and interest rate are stationary at first difference. The long-run and short-run mechanism of interaction between inflation and its determinants were examined using the Augmented Engle-Granger (AEG) Co-integration test and error Correction Mechanism (ECM) model.

Ndidi (2013) empirically examines the determinants of inflation in Nigeria using secondary data on inflation, money supply, trade openness, exchange rate and interest rate spanning the period 1970-2010. The data were analyze using ADF and PP tests for stationarity, Co-integration test for the long run relationship amongst the series and Error correction model to capture the convergence of the inflation determining factors to achieving long run equilibrium. The results found that expected inflation, measures by the lagged term of inflation, money supply significantly determine inflation, while trade openness, income level, exchange rate and interest rate are found to be significant with in the short run but in the long run none of the variables is found to be significant. The study recommends that government provide an enabling environment to industries, so as to gear up output, which will in turn help reduce homemade inflation and also the use of contractionary monetary policy to reduce inflation in Nigeria.

Alexender et al, (2015) investigated the main determinants of inflation in Nigeria for the period of 1986-2011. The ADF test revealed that all the variables are stationary after first and second difference. The co-integration result reveals long run equilibrium relationship between the rate of inflation and its determinants. The Granger causality test revealed evidence of a feedback relationship between inflation and its determinants. The estimated VAR result showed that fiscal deficits, exchange rate, import of goods and services, money supply and agricultural output have a long run influence on inflation rate in Nigeria. Only lending rate influenced inflation in the short and long run horizon. The variance decomposition and impulse results shows that own-shock were significantly responsible for the variation and innovations in all the variables in the equation. The study recommends that the monetary authority should encourage a lending policy that promotes investment as well as retention of desired level of money supply and interest rates that reduces inflation rate in Nigeria.

Ifionu and Ibe (2015) investigated the impact of Inflation, Interest rate and Real Gross Domestic Product on stock prices of quoted companies on the Nigerian Stock Exchange (NSE). Times series data was used covering the period 1985-2012. The stationary properties of the data were tested using Augmented Dickey-Fuller (ADF) and Phillips Perron (PP) unit root tests. They were all integrated at order I (1). The Johansen Multivariate Cointegration test indicates the existence of long-run equilibrium relationship among the variables in the model. There are no causal relationships between the variables based on the Granger Causality test result. Good fit for the modelresult indicates that $96.8 \%$ of variations in the dependent variable were as a result of changes in the independent variables. the findings suggest that inflation was the most important variable influencing stock prices in Nigeria.

Amaefula (2016) examines whether long-run equilibrium relationship exist between interest rate andinflation in Nigeria. The data sets on interest rate and inflation covered the period 1995 to 2014. Using ADF all the variables were not stationary at I (0) but became stationary at I (1). Johansen co-integration test was adopted to ascertain 
whether there is the existence of long run relationship between the two variables and vector error correction model (VECM) of granger causality was also employed to accommodate the long run and short run relationship and to find out whether the flow of relationship is bi-directional or unidirectional. The results show evidence of long-run equilibrium relationship between the two variables with strong evidence of unidirectional granger causality flow from interest rate toinflation rate at the long-run. The finding has empirical implication to monetary policy makers in areas of microeconomic planning in Nigeria

Udoh and Isaiah (2018) estimate the dynamic model for inflation in Nigeria using quarterly data spanning 1995 to 2016. Four dynamic models: level lagged variables, differenced lagged variables, log-transformed lagged variables and differenced log-transformed lagged variables were considered. The best predictive model was selected based on the Schwarz Information Criterion (SIC) value. From the empirical results, the level form models performed better than the differenced form models. The level lagged model was the preferred model among the selected models. Predictions obtained from the model indicate that the model is stable as actual interest rate values, fall well within the computed $95 \%$ prediction interval. The study concludes that previous values of interest rate and money supply are significant in predicting future inflation rates in Nigeria.

\section{Theoretical Framework}

The Keynesians describe the relationship between growth money supply and the level of prices in terms of the ease of access to money. The quantity of money in circulation should have a direct impact on the level of aggregate demand for goods and services in an economy. Scarcity of money constrains demand for goods and services while a glut will energize demand. Thus, demand-pull inflation would arise when aggregate demand rises above aggregate supply. One of the underlying arguments is that changes in income influence the money stock but not the reverse Mbutor (2014).

\subsection{MODEL AND DATA}

Data used in this research, were sourced from world development indicators (WDI) of the World Bank (WB) for the entire periods of study $1970-2016$. The choice of the study period was based on the availability of data on most of the variables. Consumer price index (CPI) in this study is a proxy for inflation for Nigeria. While Broad Money is a proxy for money supply in the economy, and GDP per capita is a measureof economic growth whereas the lending interest rate is the interest rate of the country. Exchange rate is a measure of official exchange rate. All data are in logarithm form foruniformity of interpretations and easy measurements. The study makes use of the Autoregressive Distributed Lag Model (ARDL) as the econometric techniques for thoroughly analyzing both the short-run and long-run effects of the interest rate on inflation. This study will best be understood using the Keynesian theory of inflation. The study utilized liquidity preference Equation to derive the inflation function with inflation as the dependent variable and interest rate as one of the independent variables among others.

$\mathrm{M}_{\mathrm{t}} / \mathrm{P}=\alpha \mathrm{Y}^{\beta 1} \mathrm{r}^{\beta 2}$

Where: $\mathrm{M}_{\mathrm{t}}$ is money demand, $P$ is price level, $Y$ is the national income and $r$ is the rate of interest while $\beta_{1} \& \beta_{2}$ are just coefficients (Danlami et al, 2018). The equation is just showing that the total real money demand is being influenced by the level of income in the economy and the interest rate.Therefore, the final inflation function is presented in Equation 3

$\mathrm{INF}=\mathrm{f}\left(\mathrm{M}_{2}, \mathrm{Y}, \mathrm{r}\right)$

Equation 3 can be presented in an econometric log form/function as follows

$\operatorname{lnINF}_{\mathrm{t}}=\beta_{0}+\beta_{1} \operatorname{lnMS} \mathrm{S}_{\mathrm{t}}+\beta_{2} \operatorname{lnGDP}_{\mathrm{t}}+\beta_{3} \ln \mathrm{INR}_{\mathrm{t}}+\beta_{4} \ln \mathrm{REX} \mathrm{X}_{\mathrm{t}}+u_{\mathrm{t}}$

Where $\ln I N F_{t}$ is a $\log$ of inflation, $\ln 2_{t}$ is a $\log$ of the money supply, $\ln$ GDP $_{t}$ is a log of GDP representing the level of economic growth ' $\mathrm{Y}$ ', $\ln I N R_{t}$ is a log of lending interest rate. In addition, we include $\operatorname{lnEXC_{t}}$ which is the Exchange rate as a measure of official exchange rate, $\beta_{\mathrm{i}}$ and $\delta$ are parameters/coefficients of the variables and time trend, $\mathrm{t}$ is the time signifies time series data to check the effect of time on inflation (time trend) and $u$ is the error term.

\subsection{Model Specification}

\section{(i) Unit Root Test}

When data exhibit unit root, it means they are non-stationary. When non-stationary series data is regressed on another non-stationary data, it will lead to spurious or non-sense regression.in order to avoid non-sense regression, this paper adopts the Augmented Dickey Fuller Test (ADF) with Philip-Perron (PP) test and Kwiatkowski-PhillipsSchmidt-Shin test (KPS) to serve as the robust check. The unit root model is written as:

\section{Intercept}

$\Delta \mathrm{Y}_{\mathrm{t}}=\beta_{0}+\beta_{1} \mathrm{Y}_{\mathrm{t}-1}+\sum_{i=1}^{k} \phi \Delta \mathrm{Yt}-\mathrm{i}+u_{\mathrm{t}}$

Trend and Intercept

$\Delta \mathrm{Y}_{\mathrm{t}}=\beta_{0}+\beta_{1} \mathrm{Y}_{\mathrm{t}-1}+\beta_{2} \mathrm{t} \quad \sum_{i=1}^{k} \phi \Delta \mathrm{Yt}-\mathrm{i}+u_{\mathrm{t}}$

Where $u_{\mathrm{t}} \mathrm{is}$ the residual term and $\mathrm{Y}_{\mathrm{t}}$ is the time series variables. 
The ARDL is used for both testing the long-run relationship and estimating the coefficients of long-run parameters among the variables which are I (1) and I (0). The ARDL model for this paper is presented in equation (5) as follows:

$\Delta \operatorname{lnINF} F_{\mathrm{t}}=\phi_{0}+\sum_{i=1}^{k} \phi \mathrm{i} \Delta \operatorname{lnINFt}-\mathrm{i}+\sum_{i=0}^{k} \phi \mathrm{i} \Delta \operatorname{lnGDPt}-\mathrm{i}+\sum_{i=0}^{k} \phi \mathrm{i} \Delta \ln I N R \mathrm{t}-\mathrm{i}+\sum_{i=0}^{k} \phi \mathrm{i} \Delta \ln E X C \mathrm{t}-\mathrm{i}+$ $\sum_{i=0}^{k} \phi \mathrm{i} \Delta \ln M S 2 \mathrm{t}-\mathrm{i}+\beta_{1} \ln \mathrm{MS}_{2 \mathrm{t}-1}+\beta_{2} \operatorname{lnGDP}_{\mathrm{t}-1}+\beta_{3} \ln I N R R_{\mathrm{t}-1}+\beta_{4} \ln \mathrm{EXC}_{\mathrm{t}-1}+\beta_{5} \ln \operatorname{lNF}_{\mathrm{t}-1}+u_{\mathrm{t}}$

Where $\beta_{1-} \beta_{5}$ are long run coefficients and $\phi_{1} \phi_{5}$ are short run coefficients, the rest as defined in the previous Equations.

The long-run and short-run equations are presented in equation (6) and (7) as follows:

$\operatorname{lnINF}_{\mathrm{t}}=\beta_{1}+\sum_{i=1}^{k} \beta 1 \mathrm{ilnINFt}-\mathrm{i}+\sum_{i=0}^{k} \beta 1$ ilnMS2t $-\mathrm{i}+\sum_{i=0}^{k} \beta 1$ ilnGDPt $-\mathrm{i}+\sum_{i=0}^{k} \beta 1$ ilnINRt $-\mathrm{i}+$ $\sum_{i=0}^{k} \beta 1 \mathrm{ilnEXCt}-\mathrm{i}+u_{\mathrm{t}}$

$\Delta \operatorname{lnINF} F_{\mathrm{t}}=\phi_{2}+\sum_{i=1}^{l} \phi 2 \mathrm{i} \Delta \ln I N F t-\mathrm{i}+\sum_{i=0}^{l} \phi 2 \mathrm{i} \Delta \operatorname{lnGDPt}-\mathrm{i}+\sum_{i=0}^{l} \phi 2 \mathrm{i} \Delta \ln I N R \mathrm{t}-\mathrm{i}+\sum_{i=0}^{l} \phi 2 \mathrm{i} \Delta \ln E X C \mathrm{t}-$ $\mathrm{i}+\sum_{i=0}^{l} \phi 2 \mathrm{i} \Delta \ln \mathrm{MSt}-\mathrm{i}+\vartheta \mathrm{ECM}_{\mathrm{t}-1}+\varepsilon_{\mathrm{t}}$.

$\mathrm{ECM}=\operatorname{lnINFt}-\varphi 0-\sum_{i=1}^{m} \delta 1$ ilnINFt $-\mathrm{i}-\sum_{i=0}^{m} \Omega 1$ ilnMS2t $-\mathrm{i}-\sum_{i=0}^{m} \lambda 1$ ilnGDPt $-\mathrm{i}+\sum_{i=0}^{m} \phi 1$ ilnINRt $\mathrm{i}-\sum_{i=0}^{k} \beta 1 \mathrm{ilnEXCt}-\mathrm{i}$.

Where ECM is the error correction term $\vartheta$ is the coefficient of the error term which measures the speed of adjustment of the variables back to equilibrium in the long-run. It also shows the percentage of deviation from the equilibrium that need to be corrected.

\subsection{ESTIMATION RESULTS}

This section presents the results of the estimation and discusses the findings of the study. The descriptive statistics are presented in Table 1 with the correlation analysis of the variables used in the study. It is observed that from Table that the average inflation rate is approximately 47.664 while that of interest rate is 17.787 . Money supply is 14.772. The average GDP per capita is approximately 1721.869 and exchange rate is approximately 76.467.29.All the variables are negatively skewed as indicated by the positive skewness coefficients for all the variables. The study also tested for data normality using Jaque-Bera normality test. The data for the study was found to be normally distributed since the $\mathrm{p}$ values for Jarque-Bera test were greater than 0.05 for all the variables. This was further confirmed that there was normal distribution of the data. All the variables depicted a normal distribution. using correlation analysis, all the variables are in logarithm form. The highest approximated value of correlation between inflation and exchange rate which is 0.968 , the lowest approximated value of correlation is between interest rate and GDP per capita which is 0.001 and all the independent variables shows positive correlation with the dependent variable.

Table 1. Descriptive Statistics and Correlation Result

\begin{tabular}{|c|c|c|c|c|c|}
\hline & INF & INR & $\mathrm{MS}$ & GDPP & $\mathrm{EXC}$ \\
\hline Mean & 46.66423 & 17.78689 & 14.77201 & 1721.869 & 76.46666 \\
\hline Median & 27.06562 & 17.69000 & 12.91732 & 1512.722 & 57.20175 \\
\hline Maximum & 183.8531 & 31.65000 & 25.12264 & 2563.092 & 253.4920 \\
\hline Minimum & 0.493799 & 8.916667 & 9.063329 & 1323.501 & 0.617708 \\
\hline Std. Dev. & 52.57786 & 4.976856 & 4.411395 & 423.5312 & 71.94625 \\
\hline Skewness & 1.071916 & 0.186287 & 0.839608 & 0.830145 & 0.426105 \\
\hline Kurtosis & 3.048971 & 3.497805 & 2.409650 & 2.178836 & 1.991855 \\
\hline Jarque-Bera & 6.897616 & 0.579930 & 4.752415 & 5.146306 & 2.613930 \\
\hline Probability & 0.031784 & 0.748290 & 0.092902 & 0.076295 & 0.270640 \\
\hline Sum & 1679.912 & 640.3280 & 531.7925 & 61987.27 & 2752.800 \\
\hline Sum Sq. Dev. & 96755.11 & 866.9185 & 681.1142 & 6278253. & 181169.2 \\
\hline Observations & 36 & 36 & 36 & 36 & 36 \\
\hline $\operatorname{lnINF} t$ & 1 & & & & \\
\hline $\operatorname{lnINR}_{t}$ & 0.475 & 1 & & & \\
\hline $\operatorname{lnMS} S_{t}$ & 0.607 & 0.122 & 1 & & \\
\hline $\operatorname{lnGDPP}_{t}$ & 0.714 & 0.001 & 0.784 & 1 & \\
\hline $\operatorname{lnEXC_{t}}$ & 0.968 & 0.619 & 0.587 & 0.639 & 1 \\
\hline
\end{tabular}

Source: Authors' 2019 using Eviews 10.

\subsection{UnitRoot Tests Results}

Even though the ARDL framework does not require pre-testing the variables for stationarity, butthe tests could justify the use of the ARDL bound testing approach to co-integration or otherwise. Consequently, we used the augmented Dickey-Fuller test (ADF), Philip-Peron Test (PP) and Kwiatkowski-Phillips-Schmidt-Shin test (KPSS) to ascertain the time series properties of the variables. Unit root test resultsis presented in Table 2(a) and Table 2(b)which shows that allthe variables were not stationary atlevel but became stationary at first difference and they 
are all integrated of order I(1).

Using augmented Dickey Fuller and Philip Perron tests results all the variables were not stationary under constant and constant and trend at level values. But the variables became stationary after first differencing both under the constant and constant and trend. This finding is in line with findings of researchers such as Danlami $e t$ $a l$, (2018), Udoh and Isaiah (2018), Ndidi (2013),Amaefula (2016), Ifionu and Ibe (2015),Umoru and Oseme (2013)

Table 2(a): Unit Root Test Using ADF and PP.

\begin{tabular}{|c|c|c|c|c|c|c|c|c|c|}
\hline \multicolumn{5}{|c|}{ Level } & \multicolumn{5}{|c|}{ First Difference } \\
\hline \multicolumn{2}{|c|}{ ADF } & \multicolumn{2}{|c|}{ PP } & \multirow[b]{2}{*}{$\begin{array}{c}\text { Constant } \\
\& \text { trend }\end{array}$} & \multirow{2}{*}{$\frac{\text { ADF }}{\text { Constant }}$} & \multicolumn{3}{|c|}{ PP } & \\
\hline Variables & Constant & Constant\&trend & Const & & & $\begin{array}{c}\text { Constant } \\
\text { \&trend }\end{array}$ & Constant & $\begin{array}{c}\text { Constant } \\
\text { \&trend }\end{array}$ & $\mathrm{I}(\mathrm{d})$ \\
\hline $\operatorname{lnINF} F_{t}$ & $\begin{array}{l}-1.41 \\
(0.562)\end{array}$ & $\begin{array}{c}-0.77 \\
(0.957)\end{array}$ & $\begin{array}{l}-1.55 \\
(0.497)\end{array}$ & $\begin{array}{c}-0.68 \\
(0.967)\end{array}$ & $\begin{array}{c}-3.43 \\
(0.017)^{* *}\end{array}$ & $\begin{array}{c}-3.72 \\
(0.035)^{* *}\end{array}$ & $\begin{array}{c}-2.72 \\
(0.080)^{*}\end{array}$ & $\begin{array}{c}-2.77 \\
(0.215)\end{array}$ & $\mathrm{I}(1)$ \\
\hline $\operatorname{lnSM} M_{t}$ & $\begin{array}{l}-1.33 \\
(0.602)\end{array}$ & $\begin{array}{l}-3.82 \\
(0.227)\end{array}$ & $\begin{array}{l}-1.44 \\
(0.553)\end{array}$ & $\begin{array}{l}-2.24 \\
(0.454)\end{array}$ & $\begin{array}{c}-4.58 \\
(0.000)^{* * *}\end{array}$ & $\begin{array}{c}-4.53 \\
(0.005)^{* * *}\end{array}$ & $\begin{array}{c}-3.29 \\
(0.023)^{* *}\end{array}$ & $\begin{array}{c}-3.22 \\
(0.097)^{*}\end{array}$ & $\mathrm{I}(1)$ \\
\hline $\operatorname{lnGDPP}{ }_{t}$ & $\begin{array}{l}-0.67 \\
(0.842)\end{array}$ & $\begin{array}{l}-1.47 \\
(0.821)\end{array}$ & $\begin{array}{l}-0.05 \\
(0.947)\end{array}$ & $\begin{array}{l}-3.08 \\
(0.126)\end{array}$ & $\begin{array}{c}-3.67 \\
(0.009)^{* * *}\end{array}$ & $\begin{array}{c}-3.56 \\
(0.048)^{* *}\end{array}$ & $\begin{array}{c}-3.67 \\
(0.009)^{* * *}\end{array}$ & $\begin{array}{c}-3.56 \\
(0.048)^{* * *}\end{array}$ & $\mathrm{I}(1)$ \\
\hline $\operatorname{lnINR} R_{t}$ & $\begin{array}{l}-2.37 \\
(0.158)\end{array}$ & $\begin{array}{l}-1.94 \\
(0.612)\end{array}$ & $\begin{array}{l}-2.38 \\
(0.155)\end{array}$ & $\begin{array}{l}-1.94 \\
(0.614)\end{array}$ & $\begin{array}{c}-5.78 \\
(0.000)^{* * *}\end{array}$ & $\begin{array}{c}-5.99 \\
(0.000)^{* * *}\end{array}$ & $\begin{array}{c}-5.78 \\
(0.000)^{* * *}\end{array}$ & $\begin{array}{c}-6.00 \\
(0.000)^{* * *}\end{array}$ & $\mathrm{I}(1)$ \\
\hline $\operatorname{lnEXC}_{t}$ & $\begin{array}{l}-1.91 \\
(0.326)\end{array}$ & $\begin{array}{l}-1.22 \\
(0.891)\end{array}$ & $\begin{array}{l}-2.03 \\
(0.271)\end{array}$ & $\begin{array}{l}-1.27 \\
(0.880)\end{array}$ & $\begin{array}{c}-5.03 \\
(0.000)^{* * *}\end{array}$ & $\begin{array}{c}-5.36 \\
(0.000)^{* * *}\end{array}$ & $\begin{array}{c}-5.02 \\
(0.000)^{* * *}\end{array}$ & $\begin{array}{c}-5.62 \\
(0.000)^{* * *}\end{array}$ & $\mathrm{I}(1)$ \\
\hline
\end{tabular}

Source: Authors' 2019 usingEviews 10 ; Note: ${ }^{* * *},{ }^{* *} \mathbb{*}^{*}$ represents statistically significant at $1 \%, 5 \% \& 10 \%$ levels and Numbers in parentheses are the p-values.

Using Kwiatkowski-Phillips-Schmidt-Shintest (KPS) result also confirm the findings of Augmented DickeyFuller test and Philip Perron test results of non-stationarity of the variables at level values but attained stationarity at first difference.

Table 2(b): Unit Root Testing Using KPSS

\begin{tabular}{lcllll}
\hline \multicolumn{2}{c}{ Level } & \multicolumn{4}{c}{ First Difference } \\
\hline Variables & Constant & $\begin{array}{l}\text { Constant } \\
\text { Trend }\end{array}$ & Constant & $\begin{array}{l}\text { Constant \& } \\
\text { Trend }\end{array}$ & Conclusion \\
\hline $\operatorname{lnINF}_{\mathrm{t}}$ & $0.68(0.463)$ & $0.17(0.146)$ & $0.29^{* *}(0.463)$ & $0.11^{* *}(0.146)$ & $\mathrm{I}(1)$ \\
$\operatorname{lnMS}_{\mathrm{t}}$ & $0.57(0.463)$ & $\left.0.13^{* *} 0.14\right)$ & $0.17^{* *}(0.463)$ & $0.15(0.146)$ & $\mathrm{I}(1)$ \\
$\operatorname{lnGDPP}_{\mathrm{t}}$ & $0.55(0.463)$ & $0.20(0.146)$ & $0.42^{* *}(0.463)$ & $0.12^{* *}(0.146)$ & $\mathrm{I}(1)$ \\
$\operatorname{lnINR}_{\mathrm{t}}$ & $0.26^{* *}(0.463)$ & $0.17(0.146)$ & $0.25^{* *}(0.463)$ & $0.07^{* *}(0.146)$ & $\mathrm{I}(1)$ \\
$\operatorname{lnLEXC}_{\mathrm{t}}$ & $0.66(0.463)$ & $0.20(0.146)$ & $0.30^{* *}(0.463)$ & $0.06^{* *}(0.146)$ & $\mathrm{I}(1)$ \\
\hline
\end{tabular}

Source: Authors' 2019 using Eviews 10; Note: ${ }^{* *}$ represents statistically significant at $5 \%$ levels and Numbers in parentheses are the p-values.

Since all the tests results shows that all the variables are integrated of the same order i.e. I (1). This implies that the simple linear regression estimate is not the appropriate estimation technique as the series are in the same order of integration, thus, bounds ARDL test is performed and we will not do this without determining our lag selection criteria. Schwarz Criteria is the basis for our lag selection because it is widely adopted.

\subsection{Lag Order Selection Criteria}

From the results of the unrestricted vector auto regressive model, using Final prediction error (FPE), sequential modified LR test statistic (each test at 5\% level), Akaike information criterion (AIC), Hannan-Quinncriteria (HQ) and Schwarz criterion (SC) information criteria revealed that lag 2 should be selected. Therefore, lag 2 is the optimal lag for this study. Hence, we lagged the variables 2 times.

Table 3. Lag Order Selection Criteria result.

\begin{tabular}{ccccccc}
\hline Lag & Logl & LR & FPE & AIC & SC & HQ \\
\hline 0 & -45.97768 & NA & $1.38 \mathrm{e}-05$ & 2.998687 & 3.223152 & 3.075236 \\
1 & 155.1061 & 331.1969 & $4.46 \mathrm{e}-10$ & -7.359184 & $-6.012396^{*}$ & -6.899891 \\
2 & 187.0787 & $43.25696^{*}$ & $328 \mathrm{e}-10^{*}$ & $-7.769334^{*}$ & -5.300221 & $-6.927295^{*}$ \\
\hline
\end{tabular}

Source: Authors' 2019 using Eviews 10. Note; * represent lags selected by different criteria's.

\subsection{Auto Regressive Distributive Lag (ARDL)}

Auto regressive Distributive Lag (ARDL) test result, estimate the variables log of inflation $\left(\operatorname{lnINF}_{\mathrm{t}}\right), \log$ of money supply $\left(\operatorname{lnMS} S_{t}\right), \log$ of GDP $\left(\operatorname{lnGDP}_{t}\right), \log$ of interest rate $\left(\ln I N R_{t}\right)$ and the log of exchange rate $\left(\operatorname{lnEXC}_{t}\right)$ was conducted using maximum lags 2 . 
Table 4. ARDL test results(1, 2, 0, 0, 0) using Schwarz Criteria

\begin{tabular}{ccc}
\hline Variable & Coefficient & T-ratio (P value $)$ \\
\hline lnINF $_{\mathrm{t}-1}$ & 1.199898 & $7.759857^{* * *}(0.000)$ \\
$\operatorname{lnINF}_{\mathrm{t}-2}$ & -0.327635 & $-2.005289^{*}(0.056)$ \\
$\operatorname{lnMS}_{\mathrm{t}}$ & -0.189295 & $-1.427068(0.166)$ \\
$\operatorname{lnMS}_{\mathrm{t}-1}$ & 0.315432 & $2.538843^{* * *}(0.018)$ \\
$\operatorname{lnGDPP}_{\mathrm{t}}$ & -1.329800 & $-3.514740^{* * *}(0.001)$ \\
$\operatorname{lnGDPP}_{\mathrm{t}-1}$ & 1.247991 & $3.410682^{* * *}(0.002)$ \\
$\operatorname{lnINR}_{\mathrm{t}}$ & 0.051905 & $0.425235(0.675)$ \\
$\operatorname{lnEXC}_{\mathrm{t}}$ & -0.009899 & $-0.159297(0.875)$ \\
$\operatorname{lnEXC}_{\mathrm{t}-1}$ & 0.130540 & $2.313955^{* *}(0.030)$ \\
Constant & 0.203561 & $0.190375(0.851)$
\end{tabular}

DW-stat 1.923 , F-stat: $1953.827^{* * *}(0.000)$

Source: Authors' 2019 using Eviews 10 . Note $,^{* * *},{ }^{* *} \&{ }^{*}$ represents statistically significant at 1\%, 5\% \& $10 \%$ level.

\subsubsection{Bound test for co-integration}

Bound test was conducted to show the existence of long-run relationships between the dependent variable in one hand and the independent variables on the other hand. Having obtained the result of F-Statistics to be 5.311632 which is above the critical values of I (0) as 3.74 and I (1) as 5.06 at $1 \%$ level of significance meaning that there is a long-run relationship among variables or in another word all the variables move together in the longrun. This result is in conformity with work of Danlami et al, (2018). This result is from ARDL estimation presented in Table 6, which is also used for the Bound test.

Table 5: Bound Test Results.

\begin{tabular}{|c|c|c|c|c|c|}
\hline \multirow[b]{3}{*}{ Model } & \multirow[b]{3}{*}{$F$-stat } & \multirow[b]{3}{*}{$\operatorname{Lag}$} & \multicolumn{3}{|c|}{ Bound test critical values } \\
\hline & & & \multicolumn{3}{|c|}{ [Unrestricted intercept \& trend] } \\
\hline & & & Level of significance & $I(0)$ & $I(1)$ \\
\hline $1981-2016$ & 5.311 & 2 & $1 \%$ & 3.74 & 5.06 \\
\hline $\begin{array}{c}\mathrm{F}\left(\operatorname{lnINF}_{\mathrm{t}} / \operatorname{lnINR}, \operatorname{lnM\mathrm {MS}_{\mathrm {t}}},\right. \\
\left.\ln \mathrm{EXC}_{\mathrm{t}}, \ln \operatorname{lnPPP}_{\mathrm{t}}\right)\end{array}$ & & & $5 \%$ & 3.74 & 5.06 \\
\hline$K=4 \& n=36$ & & & $10 \%$ & 2.45 & 3.52 \\
\hline
\end{tabular}

Source: Authors' 2019 using Eviews 10.

\subsubsection{Johansen Juselius test for co-integration}

The Johansen test for co-integration using model with Trace statistics and model with Max-Egen value confirm the findings of the ARDL Bound test for co-integration for the existence of long-run relationships among the dependent and independent variables. This result corroborates the work of researchers such as Alexander et al, (2015), Amaefula (2016), Badalona et al, (2015) and Mbutor (2014).

Table 6:Unrestricted Co-Integration Test Results.

\begin{tabular}{|c|c|c|c|}
\hline $\begin{array}{l}\text { Hypothesized } \\
\text { No. of CE(s) }\end{array}$ & Eigenvalue & $\begin{array}{c}\text { Trace } \\
\text { Statistic }\end{array}$ & $\begin{array}{l}\text { Max-Eigen } \\
\text { Statistic }\end{array}$ \\
\hline $\mathrm{C}=0$ & 0.731924 & $111.6559^{* * *}(0.000)$ & $43.44404^{* * *}(0.003)$ \\
\hline $\mathrm{C} \leq 1$ & 0.562044 & $68.21181^{* * *}(0.00)$ & $27.24599(0.055)$ \\
\hline $\mathrm{C} \leq 2$ & 0.448993 & $40.96582^{* * *}(0.001)$ & $19.66824(0.079)$ \\
\hline $\mathrm{C} \leq 3$ & 0.345294 & $21.29759^{* * *}(0.005)$ & $13.97778(0.055)$ \\
\hline $\mathrm{C} \leq 4$ & 0.198934 & $7.319812^{* * *}(0.006)$ & $7.319812^{* * *}(0.007)$ \\
\hline
\end{tabular}

Source: Authors' 2019 using Eviews 10; Note: ${ }^{* * *},{ }^{* *}$ and ${ }^{*}$ are significant at $1 \%, 5 \%$ and $10 \%$ levels respectively.

\subsection{Short run and long-run ARDL Tests.}

In this section, table 7 presents the results of the short-run and long-run ARDL coefficient of the lag 2 model and ECT value of -1.012005 indicate the speed of adjustment between the variable toward long equilibriumand also its probability is at 5\% percent level of significant meaning the whole system can get back to equilibrium at a faster speed of $101.2 \%$ in the current period.

During the long-run, the interest rate is significant and positively influencing inflation in Nigeria as it is in the short run. Specifically, a one percent increase in the rate of interest rate will lead to an increase in the rate of inflation by approximately 0.23 percent. All other variables except GDP per capita and exchange rate are significant in explaining inflation in Nigeria. This finding is consistent with the studies of Danlami et al, (2018), Bayo (2011), Adu and Marbuah (2011), Raymond (2014) and Mbutor (2014). But the finding contradicts the results of Babalola et al (2015) and Umoru and Oseme (2013) of interest rate negatively and significantly influencing inflation in Nigeria. The R-squared value of 0.99 (i.e. $99 \%$ ) indicates that $99 \%$ variation in the dependent variable (i.e. inflation) can be jointly explained by the independent variables (i.e. money supply, interest 
rate, GDP per capita and exchange rate) and only $1 \%$ variation is capture by the stochastic error term. The test of the overall significant of the model is shown by the F-statistic value of 2156.240 and its probability value of 0.000000 .

Table 7:Short- run and Long-run ARDL Results.

\begin{tabular}{|c|c|c|}
\hline $\begin{array}{c}\text { Dependent variable, } \Delta \operatorname{lnINF}_{\mathrm{t}} \text { : } \\
\text { Variables }\end{array}$ & Coefficient & $\mathrm{T}$ - ratio ( $\mathrm{p}$ value) \\
\hline $\mathrm{C}$ & -0.018292 & $-0.412290(0.684)$ \\
\hline$\Delta \ln I N F_{\mathrm{t}-1}$ & 1.545277 & $4.289819^{* * *}(0.000)$ \\
\hline$\Delta \ln I N F_{\mathrm{t}-2}$ & -0.694151 & $-2.601043^{* * *}(0.017)$ \\
\hline$\Delta \mathrm{lMS}_{\mathrm{t}-1}$ & 0.448001 & $2.369245^{* *}(0.028)$ \\
\hline$\Delta \ln \mathrm{MS}_{\mathrm{t}-2}$ & -0.327860 & $-1.712825(0.102)$ \\
\hline$\Delta \operatorname{lnGDP} \mathrm{P}_{\mathrm{t}-1}$ & -0.263439 & $-1.909342^{*}(0.070)$ \\
\hline$\Delta \operatorname{lnGDP} \mathrm{t}_{\mathrm{t}-2}$ & -0.005185 & $-0.0396920 .969)$ \\
\hline$\Delta \ln \operatorname{LINR}_{\mathrm{t}-1}$ & 1.136090 & $1.740495^{*}(.0 .096)$ \\
\hline$\Delta \ln \operatorname{LINR}_{\mathrm{t}-2}$ & -0.551045 & $-1.118216(0.276)$ \\
\hline$\Delta \operatorname{lnEXC_{t-1}}$ & 0.140615 & $2.122716^{* *}(0.046)$ \\
\hline$\Delta \operatorname{lnEXC} \mathrm{C}_{\mathrm{t}-2}$ & 0.062498 & $0.810429(0.427)$ \\
\hline Constant & -0.018292 & $-0.412290(0.684)$ \\
\hline $\operatorname{ECT}(-1)$ & -1.012005 & $-2.186898^{* *}(0.040)$ \\
\hline
\end{tabular}

$\mathrm{R}^{2}: 0.715, \mathrm{DW}$-statistics: 1.415, F-statistics: $4.7842^{* * *}(0.001)$

\begin{tabular}{cc} 
Long-run Results & \\
\hline $\ln \mathrm{NFF}_{\mathrm{t}-1}$ & 0.911176 \\
$\operatorname{lnMS}_{\mathrm{t}-1}$ & 0.191012 \\
$\ln \mathrm{FDPP}_{\mathrm{t}-1}$ & -0.049449 \\
$\ln \mathrm{NRR}_{\mathrm{t}-1}$ & 0.231906 \\
$\operatorname{lnEXC} \mathrm{t}_{\mathrm{t}-1}$ & 0.038228 \\
Constant & -0.519532
\end{tabular}

$18.86517^{* * *}(0.000)$
$1.769808^{*}(0.087)$
$-0.289223(0.775)$
$2.041738^{* *}(0.050)$
$0.695529(0.492)$
$-0.415254(0.681)$

$\mathrm{R}^{2}: 0.997, \mathrm{DW}$-stat: 1.294, F-statistics: $2156.240^{* * *}(0.000)$

Source: Authors' 2019 using Eviews 10; Note: ${ }^{* * *},{ }^{* *} \&^{*}$ represents statistically significant at $1 \%$ \& $10 \%$ levels respectively.

\subsubsection{ARDL Short Run Wald Test}

The result of the short run Wald test conducted is presented in table 11. The result has indicated that all the coefficients of the independent variables combined together have a significant effect on inflation in Nigeria. Also, from the result, the coefficients of the variables at their respective lag values such as money supply previous inflation and exchange rate have significant individual effect on the current inflation in Nigeria. Only GDP per capita and interest rate have no effect on the inflation. This result contradicts the finding of Danlami et al, (2018) but is in line with the work of Ojong et al, (2018)

Table 8:ARDL short-run Wald test results

\begin{tabular}{|c|c|c|}
\hline Null Hypothesis & F-statistics & Result \\
\hline All coefficients are zero & $4.908592^{* * *}(0.000)$ & Reject the null \\
\hline $\operatorname{lnINF}_{t}$ coefficients are zero & $10.75795^{* * *}(0.000)$ & Reject the null \\
\hline $\operatorname{lnMS}_{\mathrm{t}}$ coefficients are zero & $2.865680^{*}(0.079)$ & Reject the null \\
\hline $\operatorname{lnGDPP}_{t}$ coefficients are zero & $1.518956(0.242)$ & They are zero \\
\hline $\operatorname{lnINR}_{\mathrm{t}}$ coefficients are zero & $1.861436(0.180)$ & They are zero \\
\hline $\operatorname{lnEXC_{t}}$ coefficients are zero & $2.791261^{*}(0.084)$ & Reject the null \\
\hline Constant is zero & $0.169983(0.684)$ & Is zero \\
\hline
\end{tabular}
respectively.

\section{Post-estimation Reliability tests}

To check for the reliability and stability of the estimated model, various tests were conducted which are postestimation reliability tests, and their respective results are as follows:

Serial correlation test: the result of Breusch-Godfrey Serial Correlation LM indicated that the model is free from serial correlation, having the result of F-Statistics value of 4.350 with a probability of 0.223

Heteroskedasticity test: the result of Breusch-Godfrey heteroscedasticity test conducted shows that the variance of the error term of the estimated model is constant and desired homoscedastic with an F-Statistics value of 2.021 and probability of 0.105

Normality test: the estimated Jarque-Bera statistics with a value of 2.852 and probability value of 0.240 signifies that the errors of the estimated model are normally distributed. 
Stability of the model: figure 4 and figure 5 presents the stability sketch of the estimated model, and they show that the model is dynamically stable as indicated by the upper and lower ridges lines of the CUSUM and CUSUM of squares.

Table 9. The Results of the Autoregressive Distributed Lag Diagnostic Tests.

\begin{tabular}{cc}
\hline Test & Serial correlation \\
\hline F-stat & $4.350(0.223)$ \\
Observed R ${ }^{2}$ & $8.530(0.114)$ \\
\hline Test & Heteroscedasticity \\
\hline F-stat & $2.021(0.105)$ \\
Observed R & $9.045(0.107)$ \\
\hline Test & Normality test \\
\hline Jarque-Bera & $2.853(0.240)$ \\
\hline Test & Ramsey RESET \\
\hline F-stat & $0.327(0.275)$ \\
\hline
\end{tabular}

Source: Authors' 2019 using Eviews 10.Note; Numbers in brackets are the p-values.

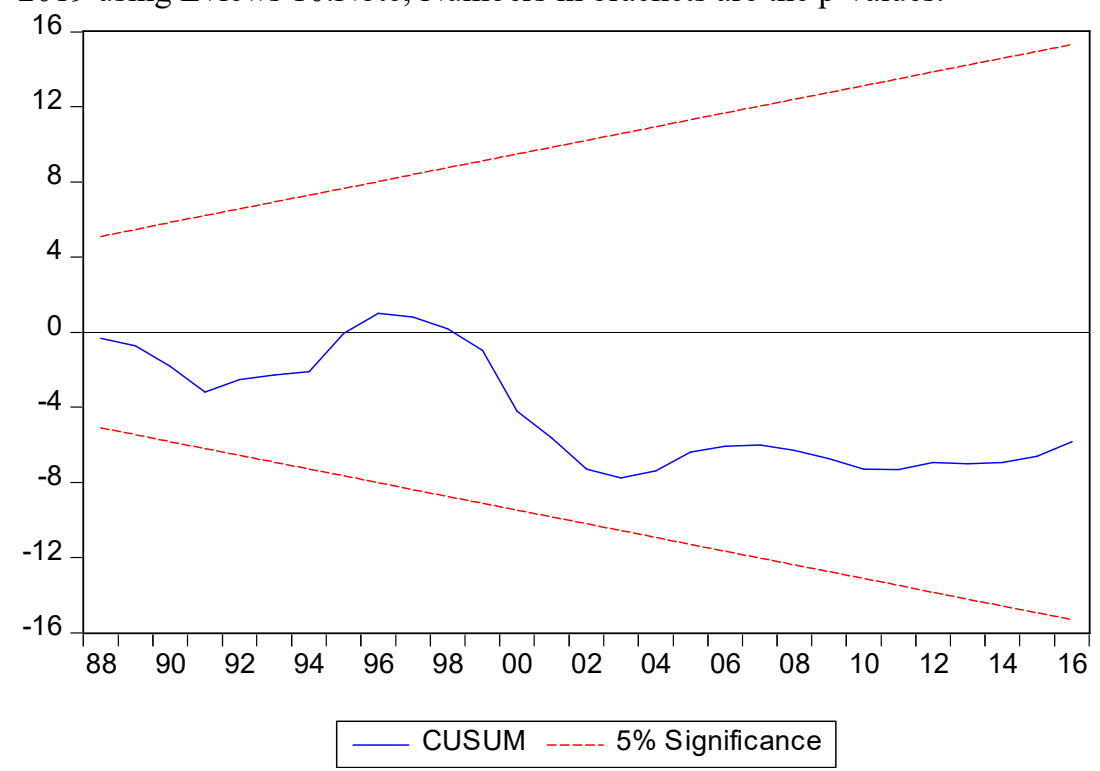

Figure 3. CUSUM Stability indicator

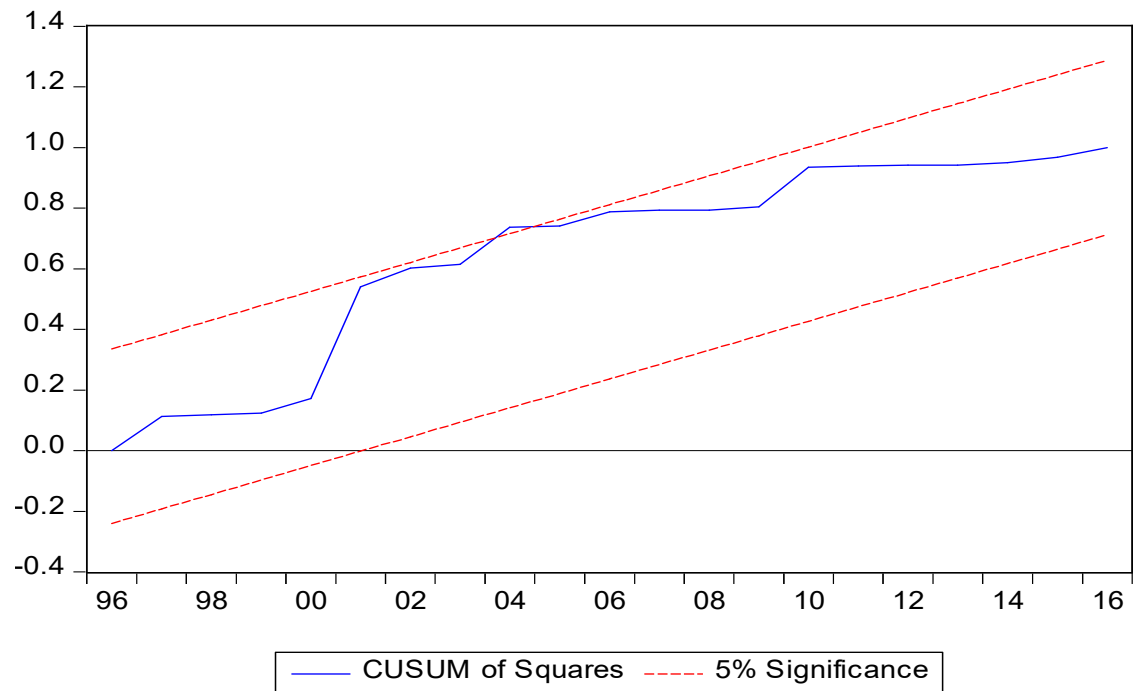

Figure 2. CUSUM ofsquares Stability indicator

\section{Conclusions}

Having estimated the model and conducted post-estimation reliability tests which the result reveal that the estimated model is highly dynamically stable and free from serial correlation as well as free from heteroscedasticity 
problem and also having the errors normally distributed. Therefore, the model fits with the analysis. The results of the estimated model reveal that interest rate is inflationary both in the short-run and long-run with significant positive influence on inflation. Also, in the same short-run, the lag values of inflation are significant in explaining the changes in the current rate of inflation. in the same period, the lag value of money supply is inflationary with significant positive effect on inflation and the same thing applies to the long-run money supply. The lag value of GDP per capita is inflationary in the short-run with negative significant effect on inflation. Though in the long-run GDP per capita is disinflationary with an inverse effect on inflation. The short-run speed of adjustment towards long-run equilibrium is around 101.2 percent, and it is highly significant. Therefore, the research concludes that the interest rate effect on inflation during the short-run and long-run in Nigeria is positive.

\section{References}

Adu, G. and Marbuah, G. (2011). Determinants of inflation in Ghana: An Empirical Investigation, South African Journal of Economics (SAJE), 79 (3):251-269. Retrieved 22 $2^{\text {nd }}$ June from http://hdl.handle.net/10.1111.j.1813-6982.2011.01273.x

Ajayi, S.A., Oladipo, O.A., Ajayi, L.B., and Nwanji, T.I. (2017) Interest Rate and Economic Growth: The Case of Nigeria, International Review of Business Research Papers, 13(1): 141-150.

Alexander, A.A., Andrew, H.A., and Danpome, G.M. (2015) Analysis of the Main Determinants of Inflation in Nigeria, Research Journal of Finance and Accounting, 6(2): 144-155. Retrieved $20^{\text {th }}$ March 2019 from: www.iiste.org

Amaefula, C.G. (2016) Long-Run Relationship Between Interest Rate and Inflation: Evidence from Nigeria, IOSR Journal of Economics and Finance 7(3): 24-28.

Asogu, J.O. (1990): An econometrics Analysis of the Nature and Causes of Inflation in Nigeria CBN. Economics and Financial Review, 29(29): 12-39.

Babalola, O.O., Dnalami, J.D., Akomolafe, K.J. and Ajiboye, O.P., (2015) Inflation, Interest Rates and Economic Growth in Nigeria. European Journal of Business and Management, 7(30): 91-102.

Bayo, F. (2011) Determinants of Inflation in Nigeria : An Empirical Analysis, International Journal of Humanities and Social Science, 1(18): 262-271, Retrieved 20 ${ }^{\text {th }}$ March, 2019 from www.ijihssnet.com.

Ifionu, E.P. and Ibe, R.C. (2015) Inflation, Interest Rate, Real Gross Domestic Product and Stock Prices on the Nigerian Stock Exchange: A post SAP Impact Analysis, Research Journal of Finance Accounting 6(14): 215 223. www. Iiste.org.

Mbutor, O.M. (2014) Inflation in Nigeria: How Much is the Function of Money? Journal of Economics and International Finance, 6(1): 21-27. Retrieved 20 $0^{\text {th }}$ March 2019 from http:// www.academijournals.org/JEIF.

Ndidi, E.D. (2013) Determinants of Inflation in Nigeria, Business and Management Review, 3(2): 106-114.

Odusanya, I.A. and Atander, A.A. (2010) Analysis of Inflation and its Determinants in Nigeria, Pakistan Journal of Social Sciences, 7(2): 97-100.

Okonjo-Iweala, N. (2013) is Interest Rate Another Ghost Hunting Nigeria? Vanguard News Paper, 02 September, Page 10 .

Raymond, A.R. (2014) An Econometric Analysis of Effect of Changes in Interest Rates on Inflation in Nigeria, International Journal of Economics, Commerce and Management, 2(10): 1-24. Retrieved $20^{\text {th }}$ March 2019 from http://iejcm.co.uk.

Udoh, S.N. and Isaiah, S.A. (2018) A Predictive Model for Inflation in Nigeria, CBN Journal of Applied Statistics 9(2): 103-129.

Umouru, D., and Oseme, S.A. (2013) Inflation Expectations and Interest Rate Variables in Nigeria: An Econometric Assessment of the Evidence. International Journal of Development and Economic Substainablity, 1(2): 1-12. Retrieved $20^{\text {th }}$ March 2019 from: www.ea-journals.org.

World Development Indicators at World Bank Data Base (2019). Retrieved 20 ${ }^{\text {th }}$ March, 2019. From: http://data.wordbank.org/indicators

\section{Authors Biographies}

Musa Kabiru Saidu: is a postgraduate student at department of Economics, faculty of social sciences and management sciences, Bauchi State University Gadau, Yuli Campus, Bauchi State of Nigeria.

Rabiu Maijama'a: is also a postgraduate student at department of Economics, faculty of social sciences and management sciences, Bauchi State University Gadau, Yuli Campus, Bauchi State of Nigeria and also working with the Nigeria National Petroleum Corporation (NNPC).

Mahabub Nasir: is a lecturer at the Department of General Studies, College of Basic and Preliminary Studies, Umaru Ali Shinkafi Polytechnic Sokoto, Sokoto State of Nigeria.

Hamza Aminu Sambo: is also a postgraduate student at department of Economics, faculty of social sciences and management sciences, Bauchi State University Gadau, Yuli Campus, Bauchi State of Nigeria and also working with the Enforcement Department, Social Insurance Trust Fund Office Bauchi Branch, Bauchi State of Nigeria. 